\title{
Classical biological control of insect pests of trees: facts and figures
}

\author{
Marc Kenis • Brett P. Hurley $\cdot$ Ann E. Hajek $\cdot$ Matthew J. W. Cock
}

Received: 23 October 2016/Accepted: 14 March 2017/Published online: 20 March 2017

(C) The Author(s) 2017. This article is an open access publication

\begin{abstract}
Classical biological control (CBC) is the introduction of a natural enemy of exotic origin to control a pest, usually also exotic, aiming at permanent control of the pest. CBC has been carried out widely over a variety of target organisms, but most commonly against insects, using parasitoids and predators and, occasionally, pathogens. Until 2010, 6158 introductions of parasitoids and predators were made against 588 insect pests, leading to the control of 172 pests. About $55 \%$ of these introductions were made against pests of woody plants. Establishment rates of natural enemies and success rates were higher in $\mathrm{CBC}$ projects targeting pests of woody plants than other pests. This
\end{abstract}

Guest Editors: Andrew Liebhold, Eckehard Brockerhoff and Martin Nuñez / Special issue on Biological Invasions in Forests prepared by a task force of the International Union of Forest Research Organizations (IUFRO).

M. Kenis $(\square)$

CABI, 1 Rue des Grillons, 2800 Delémont, Switzerland

e-mail: m.kenis@cabi.org

B. P. Hurley

Department of Zoology and Entomology, Forestry and Agricultural Biotechnology Institute (FABI), University of Pretoria, Pretoria 0002, South Africa

A. E. Hajek

Department of Entomology, Cornell University, Ithaca, NY 14853-2601, USA

M. J. W. Cock

CABI, Bakeham Lane, Egham TW20 9TY, UK review aims to answer the questions most commonly asked regarding $\mathrm{CBC}$ against insect pests, with particular emphasis on tree pests. The topics covered include, among others: variations in rates of successes among different systems, different target insect groups and different agents; temporal trends in CBC practices and successes; economic and environmental benefits; risks and ways to mitigate the risks; $\mathrm{CBC}$ against native pests; accidental successes through the adoption of the invasive pests by native natural enemies or accidentally introduced agents; and prospects and constraints for the practice of $\mathrm{CBC}$ in the future. Questions are answered based on the analysis of two databases, the BIOCAT2010 database of introductions of insect biological control agents for the CBC of insect pests, and a database of introductions of entomopathogens against insect pests.

Keywords Forest pests · Invasive insects - Classical biological control $\cdot$ Natural enemies $\cdot$ Impact of biological control

\section{Introduction}

Classical biological control (CBC) is defined as the introduction of a natural enemy of exotic origin to control a pest, usually also exotic, aiming at permanent control of the pest (Hajek 2004; Van Driesche et al. 2008). Since the introduction of the vedalia beetle 
(Rodolia cardinalis) to control the cottony cushion scale (Icerya purchasi) in California in 1886, over 6000 introductions of more than 2000 insect biological control agents have been carried out worldwide to control insect pests (Cock et al. 2016). Similarly, over 2000 releases of more than 500 biological control agents have been made against invasive weeds (Winston et al. 2014). Biological control of other invasive organisms, including vertebrates, molluscs and pathogens, have been less common and sometimes controversial (Van Driesche et al. 2008; Cock et al. 2010).

Invasive forest pests and, more generally, woody plant pests, have traditionally been a priority target for classical biological control, for various reasons. First, perennial forest ecosystems show several differences compared to intensively-managed agricultural ecosystems, some of which may favour the success of CBC (Pschorn-Walcher 1977; Dahlsten and Mills 1999). Second, many management methods that are often unfavourable to CBC and are practiced in agricultural systems are not permitted or not suitable in forests or on urban trees. For example, the use of insecticides is increasingly banned in many forested and urban areas worldwide. Similarly, the development of resistant varieties, a major management option against agricultural crop pests, is not a short or medium term option for trees, with the exception of fast growing agroforestry trees and certain plantation trees such as eucalyptus.

However, despite its long history of practice and successes, CBC is still poorly understood by the general public and many ecologists. The objective of this review is to answer the most common questions that are posed by the public and scientists to CBC practitioners. It will focus on the use of exotic arthropods (parasitoids and predators) and pathogens to control insect pests, i.e. other targets such as other invertebrates, vertebrates, weeds and pathogens will not be covered. The emphasis will be on insect pests of trees since this paper is part of a series of publications that have emerged from a workshop on biological invasions in forests organised in July 2016 by the IUFRO Task Force on Forests and Biological Invasions (http://www.iufro.org/science/task-forces/ biological-invasions/). However, many facts and considerations will also be valid for agricultural ecosystems.

\section{BIOCAT2010}

To answer some of the questions, we have analysed the BIOCAT2010 database of introductions of insect biological control agents for the CBC of insect pests (Greathead and Greathead 1992; Cock et al. 2016). BIOCAT2010 is a simple spreadsheet database, which sources published literature up until 2010 to provide details of all BCAs and their source country (countries), target pest(s), introduction location (including crop system) and date, whether it became established and results. Cock et al. (2016) provided a description of the database and an overview of trends in the use of insects for the $\mathrm{CBC}$ of insect pests, but did not attempt any analysis based on the target crop type. For this analysis, the database was expanded with 17 additional records from the older forestry literature which had been overlooked in the original compilation of BIOCAT (Greathead and Greathead 1992). In addition, we added four new variables, which we populated based on our (MJWC \& MK) judgement:

- Host plant The main host plants of the target insect are categorised as: woody; herbaceous; mixed (=woody and herbaceous host plants); other (not plant pests); or unclear (including unknown).

- Woody plant type For those introductions where "host plant" was categorised as "woody", the main host plants of the target insects were further categorised into: broadleaved tree; conifer; palm, fruit tree; bush; mixed.

- Woody cropping system Again for those introductions where "host plant" was categorised as "woody", the crops/cropping system was categorised as: forestry (including natural forests), orchards or other woody plantations (other trees grown for their fruits, e.g. cotton, coffee, cocoa, etc.); ornamentals and other useful plants (e.g. agroforestry); mixed; other (e.g. wild plants).

- Woody origin For each of these introductions where "host plant" was categorised as "woody" and the cropping system as "forestry" or "ornamentals/useful", the (main) target crop was categorised as indigenous or introduced for that target country. The origin was also assessed for cases in the cropping systems "mixed" and "other" when the main host plant was a forest or ornamental/ useful plant. In contrast, the origin was not assessed for the cropping system "orchards and 
other plantations" because of the uncertainty in the origin of anciently domesticated crop trees. Furthermore, we excluded cases when the main host trees where both indigenous and exotic or when the origin of the host trees was unclear.

Using these four new variables, we were able to count records by categories to address some of the questions posed. When appropriate, differences between categories were tested using Chi square tests. However, due to the high number of pseudo-replications inherent to this kind of dataset, the results have to be considered with caution.

The BIOCAT2010 database includes only insect biological control agents. Pathogens (mostly viruses, fungi and microsporidia) and nematodes have also been used in classical biological control introductions but these are far fewer (Hajek et al. 2007, 2016a). Information on pathogen and nematode introductions will be added as appropriate. Unfortunately, this information is largely based on establishment rates as numbers of introductions were considered too low to generalize about successes, although there have been some very successful programs.

\section{How does CBC work?}

The general procedures included in CBC against an exotic pest are detailed in many publications, e.g. Pschorn-Walcher (1977) and Van Driesche and Reardon (2014), who specifically focused on forest insect pests, and more general books (e.g. Van Driesche and Bellows 1996, Hajek 2004, Van Driesche et al. 2008). In brief, the recommended steps for a successful and safe CBC programme are:

- Evaluation of the problem, including pest identification and region of origin, assessment of the economic or environmental impact of the pest and identification of stakeholders;

- Establishment of collaborations between the region of origin and the region of introduction;

- Literature surveys to collect all of the available information on the pest, its natural enemies and, when available, previous $\mathrm{CBC}$ projects on the pest;

- Surveys for natural enemies in invaded areas to identify species already present and empty ecological niches;
- Selection of the region of investigation for potential natural enemies for introduction, based on the identified or assumed native range, climate similarities with the invaded region and practicality of survey;

- Collection of natural enemies in the native range and field assessments of their role as mortality factors in the region of origin;

- When possible, and where needed, preliminary studies in the native range on their biology and ecology (with focus on specificity);

- Importation of natural enemies into a certified quarantine facility in country of proposed introduction;

- Establishment of colonies of the natural enemies in the quarantine facility;

- Studies in the quarantine facility to determine the host range of the natural enemies as well as other non-target assessments and studies on biological parameters, including those informative toward potential control efficacy and optimizing rearing and release protocols;

- Prioritization of the most suitable natural enemies for release (if multiple natural enemies tested);

- If a natural enemy is deemed suitable for release based on above-mentioned studies, application for permission to release as biological control agent into the field;

- Development of release methods, including means for transport and identification of areas suitable for release and monitoring of agents;

- Release of the biological control agent(s) at selected sites, with the aim to cover the area of distribution of the pest;

- Monitor the establishment of the biological control agent/s, evaluate its impact on the pest population and test for non-target effects.

Although the general strategy for a $\mathrm{CBC}$ project has not changed very much over numerous decades, the major evolution in the recent two decades has been the larger emphasis on host range testing and assessments of other potential non-target effects, following the increasing concern for negative environmental impacts of CBC agents (Hajek et al. 2016b; see section on the risks of $\mathrm{CBC}$ below). Today, the assessment of the risk of non-target impacts is often the most time-consuming step of a $\mathrm{CBC}$ programme. 
Why don't we wait until indigenous natural enemies increase their ability to control the invasive pest?

Native natural enemies in the invaded range can adapt to attacking introduced invasive pests. The adoption rate is likely to increase over time and, in some cases, it has led to a substantial reduction in the invasive pest population. For example, the ambermarked birch leaf miner (Profenusa thomsoni), a rare species in Europe, was accidentally introduced into North America at the beginning of the twentieth century. In the 1970s, it became a severe pest of birch in Central Canada. However, in the 1990s the population of P. thomsoni crashed due to parasitism from a parasitoid of unknown origin, Lathrolestes thomsoni (previously identified as L. luteolator) (MacQuarrie 2008; Soper et al. 2015). Since this parasitoid has never been found on $P$. thomsoni in Europe (M. Kenis unpublished data), it most probably came from another host species in North America. In Massachusetts and Alaska, other native parasitoids participate in the control of $P$. thomsoni (Soper et al. 2015). A few other cases of successful control following the adaptation of native natural enemies to attacking invasives have been reported, such as the firethorn leaf miner (Phyllonorycter leucographella) in the UK (Godfray et al. 1995). However, in most cases, the adoption of an invasive species by native natural enemies results in poor or no control. In Central and Western Europe, the invasive horse-chestnut leaf miner (Cameraria ohridella) is attacked by dozens of parasitoids without any apparent effect on damage levels (e.g. Grabenweger et al. 2010). The birch case bearer (Coleophora serratella), a European species that invaded North America at the beginning of the twentieth century, has 28 parasitoids recorded in the invaded range, but parasitism rates are only between 5 and $16 \%$, as compared to 24 parasitoids responsible for $40-70 \%$ parasitism in its native range (Cornell and Hawkins 1993).

It should be noted that the population dynamics of invasive insects sometimes show a "boom and bust" pattern, where the population and damage are highest soon after introduction and then populations partly or completely collapse (e.g. Hyphantria cunea in Europe, Kenis 2005). In such cases, the cause of the population collapse is rarely investigated but could be the adoption by native natural enemies. Cornell and
Hawkins (1993) showed that parasitism of invasive insects by native parasitoids only weakly increases with time, but patterns may be different with predators and pathogens. Intuitively, invasive insects are more likely to be adopted by native natural enemies if (1) the exotic insect belongs to a group of insects that are usually attacked by polyphagous natural enemies (e.g. leaf miners, case bearers or xylophagous insects) and (2) there are, in the region of introduction, insects that are taxonomically and ecologically closely related to the invader. However, these assumptions would need to be properly tested. To sum up, native natural enemies are likely to attack invasive insects and, in some cases, may, sooner or later, partially or totally control the pest. However, the outcomes of the adoption of the invasive species by native natural enemies are rather unpredictable and, in most cases, insufficient to provide satisfactory control.

Can exotic natural enemies from the area of origin of the pest arrive accidentally?

Indeed, it often happens that exotic natural enemies of invasive insects appear spontaneously, soon or long after the introduction of the pest and, in some cases, they provide significant control. For example, several specific parasitoids of invasive eucalypt insect pests in the Mediterranean regions have been apparently introduced accidentally a few years after their hosts: e.g. Avetianella longoi, an egg parasitoid of the eucalyptus woodborer (Phoracantha semipunctata); Closterocerus chamaeleon, a parasitoid of the eucalyptus gall wasp (Ophelimus maskelli); and Psyllaephagus bliteus, a parasitoid of the red gum lerp psyllid (Glycaspis brimblecombei) (Kenis and Branco 2010; Boavida et al. 2016; Bush et al. 2016). Other classical cases of natural enemies arriving accidentally with their hosts are parasitoids of scale insects travelling in parasitized scales on plant material, such as the parasitoids of the San José scale (Diaspidiotus perniciosus) in New Zealand (Charles 1998). Some spectacular examples are also provided by insect pathogens, with establishment of pathogens not due to purposeful introductions (Hajek et al. 2016a). In particular, in the 1930s the introduced European spruce sawfly (Gilpinia hercyniae) was damaging spruce in eastern Canada and nearby areas of the US. After introductions of parasitoids began, a nucleopolyhedrovirus (GiheNPV), most probably 
introduced accidentally with the parasitoids, was reported in sawfly populations. Introductions of virus were conducted to accelerate spread and the outbreak collapse that occurred from 1938 to 1942 was largely attributed to this virus (Hajek and van Frankenhuyzen 2016). The gypsy moth nucleopolyhedrovirus (LdMNPV) was the major natural enemy in outbreak populations of gypsy moth (Lymantria dispar), in North America for many years but this virus was also not purposefully introduced and showed up after parasitoid introductions began (Hajek et al. 2016a). In 1989, epizootics caused by the fungal pathogen Entomophaga maimaiga occurred in North American gypsy moth populations. This fungus has replaced the virus as the major natural enemy attacking gypsy moth (Hajek et al. 2015). While this fungus was purposefully introduced in 1910-1911, the successful introduction probably only occurred accidentally, after 1971 (Nielsen et al. 2005; Weseloh 1998).

\section{Does CBC work?}

Until 2010, 6175 introductions of insect CBC agents were made against 588 insect pests. $33 \%$ of these introductions led to establishment and $10 \%$ resulted in satisfactory control against $29 \%$ of the pests being targeted. Considering that 172 insect species have been successfully controlled by insect CBC agents worldwide (not counting those controlled by the introduction of pathogens and nematodes), it is surprising that so many professional biologists and ecologists still question the effectiveness of CBC as a control method. While the most famous CBC successes are probably those of key agricultural pests (e.g. the cassava mealybug, Phenacoccus manihoti in Africa, Neuenschwander 2001), many also concern forest pests. Examples include the control of winter moth (Operophtera brumata) and the larch case bearer (Coleophora laricella) in North America, the chestnut gall wasp (Dryocosmus kuriphilus) in Japan, North America and Europe, Pineus aphids (Pineus pini and Pineus boerneri) in Chile, Hawaii and East Africa, and the great spruce bark beetle (Dendroctonus micans) in Europe and the Caucasus. These and many other examples are described in van Driesche and Bellows (1996), Hajek (2004), Van Driesche et al. (2008), Garnas et al. (2012), Van Driesche and Reardon (2014) and Cock et al. (2015).
Does CBC work better in forests and other perennial ecosystems than in agricultural systems?

Intuitively, forest ecosystems and semi-natural agroecosystems should be more favourable for CBC than intensively managed agro-ecosystems because the former ecosystems show a high degree of diversity in plant and animal communities. Furthermore, their stability fosters the evolution and preservation of highly structured, well-balanced natural enemy - pest complexes and should facilitate the establishment and impact of exotic CBC agents (Pschorn-Walcher 1977; Dahlsten and Mills 1999). Analysis of BIOCAT2010 reveals that, in total, $56 \%$ of the introductions of parasitoids and predators were made against pests of woody plants, representing $46 \%$ of the target pests and $58 \%$ of the target pests controlled. Establishment rates of natural enemies were numerically higher in CBC projects targeting pests of woody plants $(37 \%)$ than other pests (30\%) (Fig. 1). Similarly, successes were more often observed against tree pests than against herbaceous and other pests, with $34 \%$ of tree pests being successfully controlled compared to $24 \%$ for herbaceous pests (Fig. 1). When only CBC projects

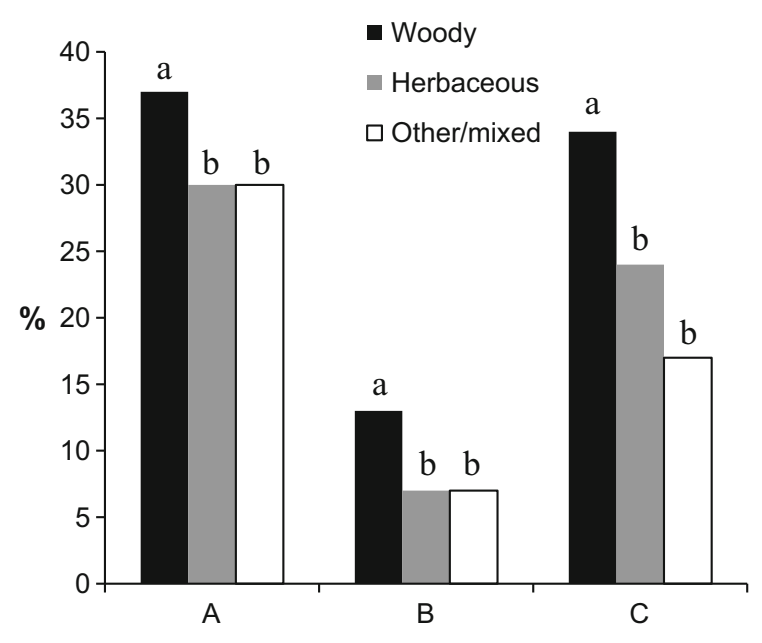

Fig. 1 Percentages of $(A)$ introductions of parasitoids and predators leading to establishment, $(B)$ introductions of parasitoids and predators leading to success, $(C)$ target species successfully controlled in CBC programmes worldwide until 2010. See text for definitions of categories. Chi square tests, $3 \times 2$ tables: $A\left(\mathrm{X}^{2}=38.4 ; d f=2 ; \mathrm{n}=6175 ; p<0.001\right)$; $B\left(\mathrm{X}^{2}=54.0 ; d f=2 ; \mathrm{n}=6175 ; p<0.001\right) ; C\left(\mathrm{X}^{2}=18.7\right.$; $d f=2 ; \mathrm{n}=693 ; p<0.001)$. Same letters above bars within a host plant category indicate homogenous groups at 0.05 level in $2 \times 2$ Chi square tests 
against woody plant pests were considered, the highest success per target was obtained against palm pests and the lowest against pests of bushes, but the difference among types of woody plants was not significant (Fig. 2). Similarly, there was no difference in the success rates between forest pests, pests of nonforestry plantations/orchards and pests of ornamental trees (Fig. 3).

The same has been observed for releases of pathogens and nematodes, where establishment was greater for insect hosts in forests and tree crops (63-67\%) compared with all other types of habitats (Hajek et al. 2007).

Are $\mathrm{CBC}$ success rates different when the tree is native or exotic?

The BIOCAT2010 catalogue includes 731 cases of introductions of pests of forestry or ornamental/useful woody plants for which the main host plants could be categorised as indigenous (507 cases against 55 pest species) or exotic (224 cases against 53 species). The rate of successful introductions was $24.7 \%$ and $52.7 \%$ for indigenous and exotic host plants, respectively $\left(\mathrm{X}^{2}=55.0 ; d f=1 ; \mathrm{n}=731 ; p<0.001\right)$. In exotic woody plant systems, $21.0 \%$ of the introductions led to satisfactory control against $35.8 \%$ of pests being targeted. These rates were only $4.9 \%\left(\mathrm{X}^{2}=45.1\right.$; $d f=1 ; \mathrm{n}=731 ; p<0.001)$ and $20.0 \%\left(\mathrm{X}^{2}=3.4\right.$; $d f=1 ; \mathrm{n}=108 ; p=0.066)$ in indigenous woody plant systems. This lower success against pests of indigenous trees could be explained by the fact that a few programmes to control exotic pests of indigenous trees have involved the unsuccessful introduction of many biological control agents, such as the programmes against the gypsy moth, the balsam wooly adelgid (Adelges piceae), or the European spruce sawfly in North America. It could also be due to the fact that a natural enemy may be more efficient when its host insect feeds on the host plant of origin, than when the host insect has adopted a new host plant, i.e., a host plant that is native to the area of introduction but not the area of origin.

Has the CBC success rate increased with time?

Considering that $\mathrm{CBC}$ techniques have improved and that, in recent years, the selection of $\mathrm{CBC}$ agents to be introduced is more rigorous (Hajek et al. 2016b), the success rate of CBC introductions should be higher than in the past. Interestingly, the trend in the establishment rate was higher at the beginning of the twentieth century than in the mid-twentieth century and increased again in the last decades (Fig. 4). The success rate shows the same pattern for CBC projects targeting woody plant pests but not pests of herbaceous plants (Fig. 4). The drop in establishment and success rates since 2000 is at least partly due to delays

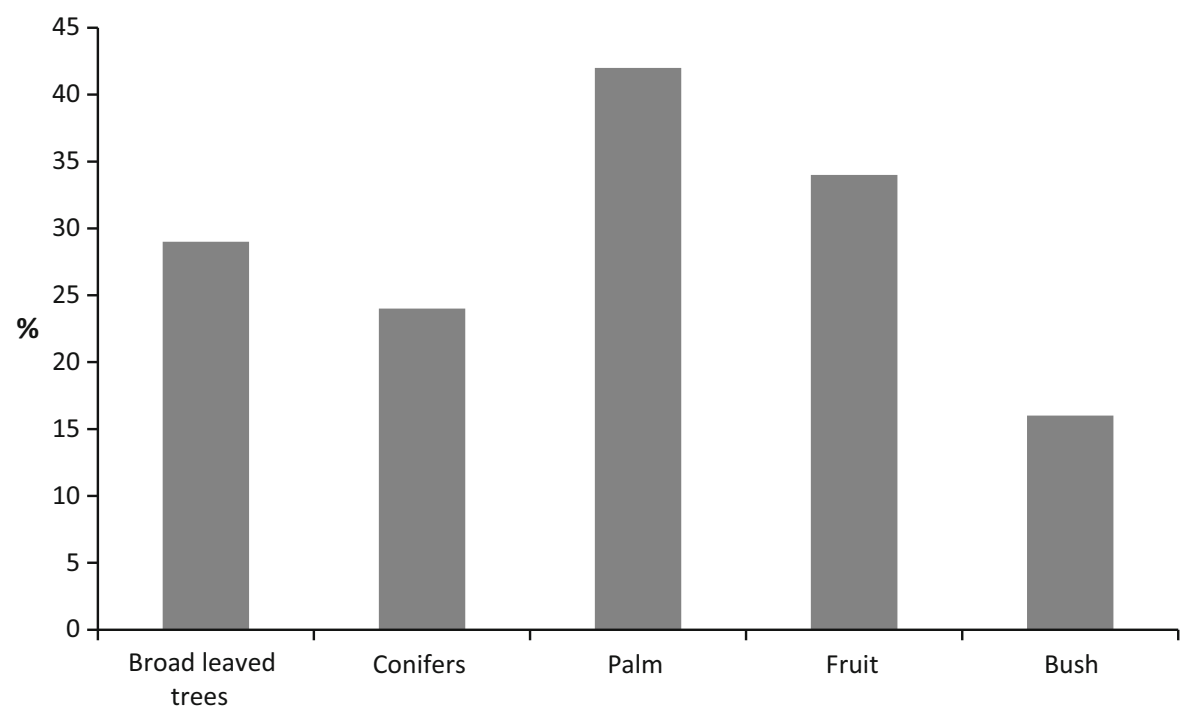

Fig. 2 Percentages of target species successfully controlled in CBC programmes worldwide until 2010, on different types of woody plants. Chi square test, $2 \times 5$ table: $\mathrm{X}^{2}=9.1 ; d f=4 ; \mathrm{n}=331 ; p=0.059$ ) 


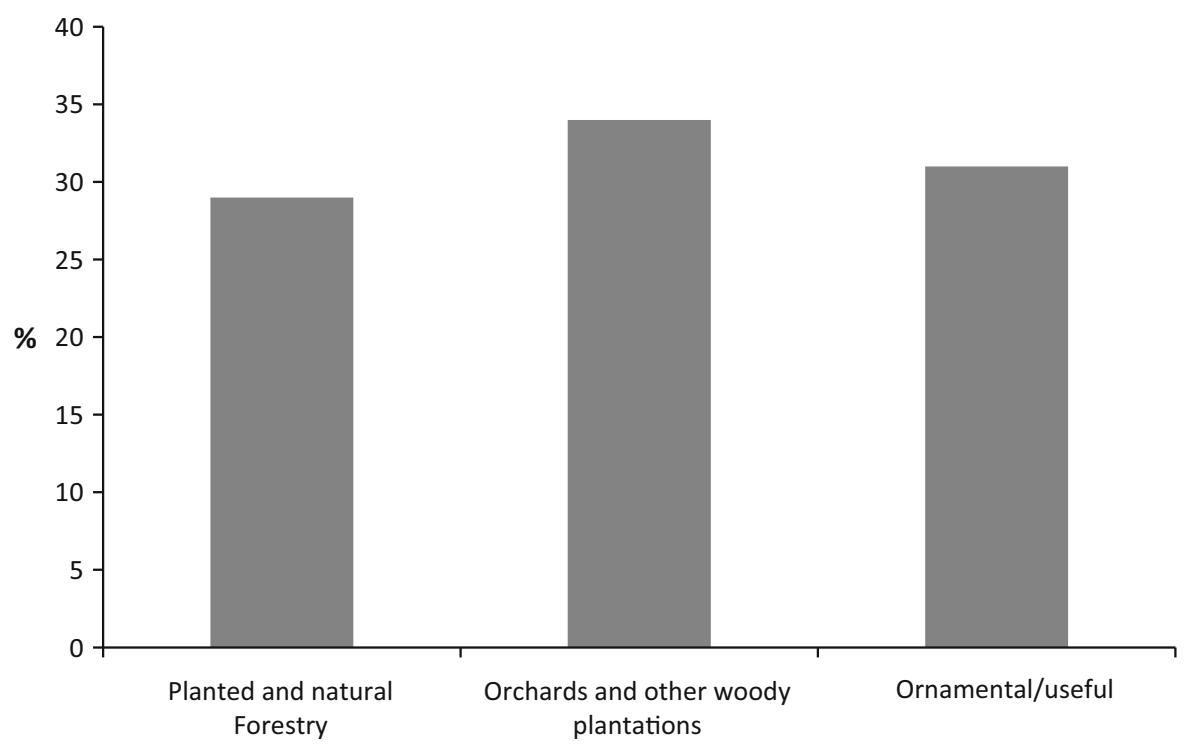

Fig. 3 Percentages of target species successfully controlled in CBC programmes worldwide until 2010, in different woody cropping systems. See text for definitions of categories. Chi square test, $2 \times 3$ table: $\mathrm{X}^{2}=0.7 ; d f=2 ; \mathrm{n}=317 ; p=0.689$ )

Fig. 4 Percentages of successful establishment of parasitoids and predators, and percentages of introductions of parasitoids and predators leading to successful control in CBC programmes against plant pests on woody and herbaceous plants presented per decade, until 2010

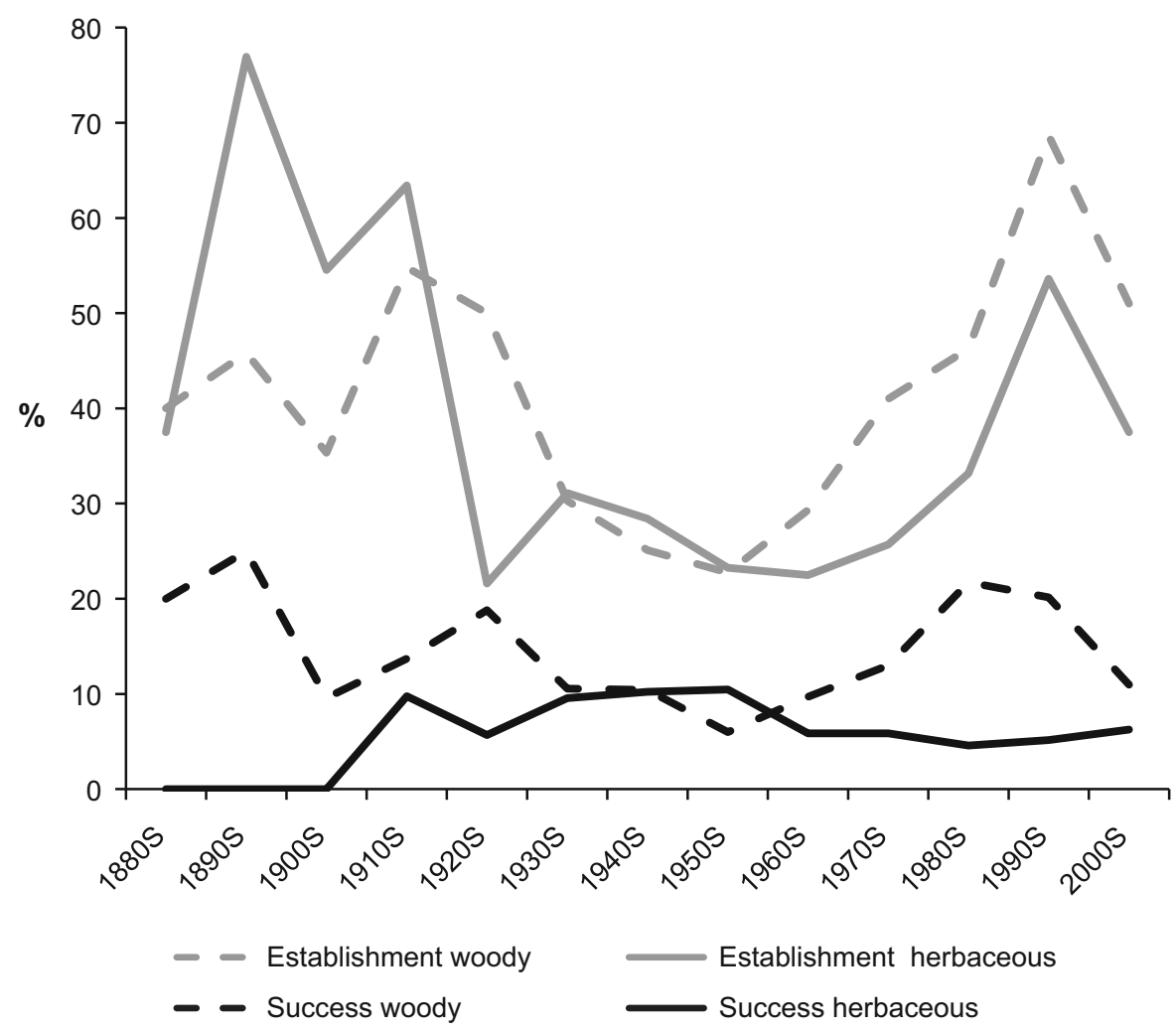

in evaluating and reporting establishment and successes, since BIOCAT2010 only includes literature published until 2010. The high establishment and success rates observed in the early 1900 s can be explained by the multiple use of a few successful agents in different locations (Cock et al. 2016). 
What are the expected economic benefits of $\mathrm{CBC}$ ?

$\mathrm{CBC}$ is one of the few pest management techniques that aim at permanent control, where no action is needed after the CBC agents have been released and distributed throughout the invaded range. Therefore, in the long term, CBC should lead to huge benefits. However, the fact that the benefits persist over time is also one of the reasons that calculations of benefits is difficult. In general, the impacts of CBC are poorly documented, for various reasons, among which urgency (the need for an immediate solution rather than base-line studies), their complexity (e.g. multisectoral benefits), lack of funding or government prioritization for post-release monitoring, and the fact that the success may be seen as self-evident and therefore not worth quantifying (Gutierrez et al. 1999; Cock et al. 2015).

Data on economic benefits does exist for several agricultural pests. This includes the cassava mealybug and mango mealybug $\mathrm{CBC}$ projects in Africa with estimated cost:benefit ratios over 40 years of 1:199-1:738, and 1:808, respectively (Cock et al. 2015 and references therein). Other examples are provided in Gutierrez et al. (1999) and Hill and Greathead (2000). For pests of forest and ornamental trees, cost:benefit data are very scarce. For the CBC project of the blue gum psyllid (Ctenarytaina eucalypti) in California, Dahlsten et al. (1998) calculated a cost:benefit ratio of 1:9-1:24 but stated that these numbers were very conservative because only the savings made on pesticide use by 13 growers were included in the benefit calculation whereas other benefits were not counted, such as those due to improved foliage quality and quantity, avoidance of tree replacement and possible environmental and health considerations. Hill and Greathead (2000) and Tisdell (1990) provide a couple of older examples of cost:benefit calculations in CBC in forestry, e.g. 1:15 for the winter moth (Operophtera brumata) (over 30 years), 1:19 for the European spruce sawfly (over 14 years) in Canada but only 1:2.5 for the biological control of the Sirex woodwasp (Sirex noctilio) (over 40 years) in Australia, partly because the nematode (Deladenus siricidicola) biological control agent has to be re-applied regularly. Taken globally, the cost:benefit ratios of $\mathrm{CBC}$ programmes are much more advantageous than those of chemical control programmes, which were estimated at an average of 1:2.5 in Australia by Tisdell (1990).

Can there also be ecological benefits?

In the past, $\mathrm{CBC}$ against insect tree pests was carried out nearly exclusively for economic purposes, even though ecological benefits were achieved as "side effects", through a reduction in pesticide use or when the $\mathrm{CBC}$ was targeting pests of native trees also threatened in natural ecosystems. In recent decades, however, CBC programmes have been increasingly developed for the primary purpose of protecting biodiversity and natural ecosystems (Van Driesche et al. 2010, 2016). An example of CBC of a tree pest aiming at the conservation of natural ecosystems is the introduction of the coccinellid predator Hyperaspis pantherina to control the invasive orthezia scale (Insignorthezia insignis) in St Helena. In the 1990s, this South American scale was driving an endemic gumwood tree (Commidendrum robustum) to extinction until the introduction of the coccinellid saved the tree (Fowler 2004). Other recent examples of programmes with ecological motivations include, among others, the CBC of the cottony cushion scale using the vedalia beetle in Ascension Island and the Galapagos to protect many native plants and the CBC of the erythrina gall wasp (Quadrastichus erythrinae) using parasitoids in Hawaii to preserve the indigenous wiliwili tree (Erythrina sandwicensis) (Van Driesche et al 2010).

Can CBC eradicate a pest or a non-target species?

The aim of CBC is not to eradicate a pest but rather to lower its populations below a damage threshold. In successful CBC programmes, after the establishment of the natural enemies, an ecological equilibrium at lower population levels is reached between the pest and its natural enemies. To our knowledge, there is no report of eradication of a target insect following a CBC programme on a continent. There are, however, some rare reports of potential eradication events on islands. A famous one is the possible eradication of the zygaenid coconut moth (Levuana iridescens) following the introduction of the exotic tachinid parasitoid Bessa remota (Kuris 2003). However, proving the extinction of this insect species within the Fiji 
archipelago is a major task, which has not been systematically undertaken.

Do parasitoids and predators work equally well?

More than three times more introductions of parasitoids (2588) were made on woody plant pests than predators (838). The establishment rate was $39.9 \%$ for parasitoids and $29.4 \%$ for predators $\left(X^{2}=7.9\right.$; $d f=1 ; \mathrm{n}=3419 ; p=0.005)$. The percentage of introductions leading to successes was higher with parasitoids $(13.5 \%)$ than with predators $(9.8 \%)$ $\left(\mathrm{X}^{2}=30.3 ; \quad d f=1 ; \mathrm{n}=3419 ; \quad p<0.001\right)$. The higher use of parasitoids is probably also due to the fact that, in general, parasitoids tend to be more specific than predators and, thus, more acceptable for CBC. But there are many exceptions. For example, the tachinid parasitoid Compsilura concinnata, introduced in North America against the gypsy moth, has more than 200 known hosts (Elkinton and Boettner 2012). On the other hand, successful predators such as the coccinellids Hyperaspis pantherina and Rodolia cardinalis, released against the orthezia scale in $\mathrm{St}$ Helena and against the cottony cushion scale in the Galapagos, respectively, or the beetle Rhizophagus grandis, released against the great spruce bark beetle (Dendroctonus micans) in Europe, are specific (Grégoire et al. 1992; Van Driesche et al. 2010; Cock et al. 2015). Thus, predators should not be excluded a priori based on the criterion of specificity.

\section{Can $\mathrm{CBC}$ work against native pests?}

Traditionally, CBC has targeted exotic pests with the aim to re-create a part of the natural enemy complex that controls the pest in its area of origin. However, throughout the history of $\mathrm{CBC}$, native pests have occasionally been targeted using exotic CBC agents. Famous examples include the sugar cane borer (Diatraea saccharalis) with the Asian braconid wasp Apanteles flavipes in Barbados and subsequently much of the Neotropics, and the geometrid moth Oxydia trichiata by the scelionid wasp Telenomus alsophilae introduced from the USA to Colombia (Carl 1982). The coconut moth in Fiji eliminated by the tachinid parasitoid B. remota, introduced from Malaya, is also often cited as an example, although, in this case, the indigenous status of the moth in Fiji is still a matter of debate (Kuris 2003).
Pimentel (1963) was the first to advocate the potential of CBC to control native pests. He developed the theory of "new associations", suggesting that natural enemies that have never been in contact with a host, or prey, would perform better than natural enemies with which it co-evolved. In the 1980's this theory was further developed and advocated by other authors (Carl 1982; Hokkanen and Pimentel 1984, 1989) and the approach of controlling native species by the introduction of exotic natural enemies was later named "neo-classical biological control" (NCBC) (Lockwood 1993). Consequently, there were several NCBC projects during the 1980s and 1990s. In forestry, an important collaborative programme between the Canadian Forest Service and CABI (Formerly IIBC, International Institute of Biological Control), involving the first author, specifically focused on the control of a dozen native Canadian tree pests using natural enemies from related hosts/ prey in Europe (details on these projects are found in several chapters of Mason and Huber 2002). The programme ran between 1981 and 1996; however, hardly any natural enemies were released and none of these projects were successful, for two reasons. First, when there was no direct taxonomic and ecological relative in Europe to the target Canadian pest, the natural enemies found on other insects in Europe were either too specific to attack the target pest or too polyphagous to be considered for introduction. This was the case for example, with the project aiming at controlling the hemlock looper (Lambdina fiscellaria fiscellaria), which has no congeneric species in Europe (West and Kenis 1997) and the mountain pine beetle (Dendroctonus ponderosae), of which the only European congeneric, D. micans, has a totally different ecology (Safranyik et al. 2002). Secondly, when taxonomically and ecologically closely related pest species occurred in Europe, the target native species and the source host species had very similar natural enemy complexes (often congeneric parasitoid species), and thus there were no empty ecological niches that could be filled by an exotic natural enemy. Therefore, it was feared that a new natural enemy would interact with native natural enemies and may cause intra-guild competition, displacement and secondary interactions. This was the case in the projects targeting the spruce budworm (Choristoneura fumiferana) (Nealis et al. 2002), the spruce budmoth (Zeiraphera canadensis) (West et al. 2002) and the spruce 
cone maggots (Strobilomyia spp.) (Sweeney et al. 2002). Based on this experience, we do not think that $\mathrm{CBC}$ will represent a major control strategy for native pests in the future. In addition, most previous successes against native pests, for example the parasitoids that successfully controlled the coconut moth and $O$. trichiata, would not be possible in the present situation because of their polyphagy.

In their analysis of releases of pathogens and nematodes for CBC, Hajek et al. (2007) showed that levels of establishment did not differ when the host insect was native versus exotic. As an example, the rhinoceros beetle Oryctes rhinoceros was introduced to many islands in the South Pacific. A virus isolated from native Malaysian populations of $O$. rhinoceros was introduced to locations both where the beetle was native and where it had been introduced, with establishment and control in both situations (Hajek et al. 2016a). The Japanese fungal pathogen of gypsy moth (E. maimaiga) also has been providing control both in northeastern North America where the gypsy moth was introduced and in Bulgaria, where it is native (Georgiev et al. 2014; Hajek et al. 2016a).

Are all invasive insects good targets for CBC?

The success of invasive pests in the region of introduction and the resulting damage is often explained by the enemy-release hypothesis, which states that invasive species do better in their area of introduction because they are released from their natural enemies, such as parasitoids, predators and pathogens, that control them in their area of origin (Jeffries and Lawton 1984; Keane and Crawley 2002). However, other factors may favour the invasive species in its new environment (Colautti et al. 2004). One factor that is particularly important for invasive tree pathogens and pests is that, in the invaded range, the new organisms will encounter plants that have not coevolved with the invader and, consequently may lack resistance mechanisms. This phenomenon explains the success of several dramatic plant pathogen invasions such as those of the chestnut blight (Cryphonectria parasitica), Dutch elm disease (Ophiostoma novo-ulmi), sudden oak death (Phytophthora ramorum) and ash dieback (Hymenoscyphus fraxineus) (Pautasso et al. 2013; Lovett et al. 2016), but also invasions by insect pests such as the emerald ash borer (Agrilus planipennis) and the viburnum leaf beetle (Pyrrhalta viburni) Rebek et al. 2008; Desurmont et al. 2011). In cases where host resistance/susceptibility is a significant factor influencing the population density of the pest, the introduction of CBC agents may have minimal impact on the damage intensity. For example, an extensive CBC programme against the balsam woolly adelgid in North America involving the introduction of more than 700,000 individuals representing about 33 predator species in the mid-twentieth century did not provide any significant control (Montgomery and Havill 2014) and it remains to be seen whether the ongoing programmes against the emerald ash borer will be more successful (Van Driesche and Reardon 2014). In these cases, CBC can at best be complementary to other methods such as the development of resistant plant varieties, although the latter method has various constraints in forestry (Henery 2011), and with trees in general.

Besides the influence of plant resistance, the success rate of $\mathrm{CBC}$ also differs between insect orders. An examination of the BIOCAT2010 database shows that, for woody plants, more than $50 \%$ of all introductions against insects targeted hemipteran Sternorrhyncha (scales, aphids and whiteflies) (Fig. 5). This bias is justified considering that the rate of introductions leading to successes is also highest on Sternorrhyncha (Fig. 6). Interestingly, sawflies also have a high success rate whereas moths show the lowest rate, with only about $2 \%$ of all introductions leading to successful control. For pathogens and nematodes, by far the highest levels of establishment were against Hymenoptera, which in this case included sawflies and the woodwasp Sirex noctilio. In fact, these examples included only a few viruses against the sawflies and one nematode against the woodwasp, but these natural enemies were initially so successful that they were then released in additional locations (Hajek et al. 2007).

Other factors that may hamper the success of CBC programmes are the lack of specific natural enemies or the low importance of natural enemies in the population dynamics of the pest in the area of origin. For example bark beetles (Curculionidae: Scolytinae) are usually attacked by polyphagous natural enemies, which are generally considered of low importance in the regulation of bark beetle populations (Kenis et al. 2004). Furthermore, in most cases lack of specificity of many natural enemies of bark beetles would make them unsuitable for introduction. Consequently, there 


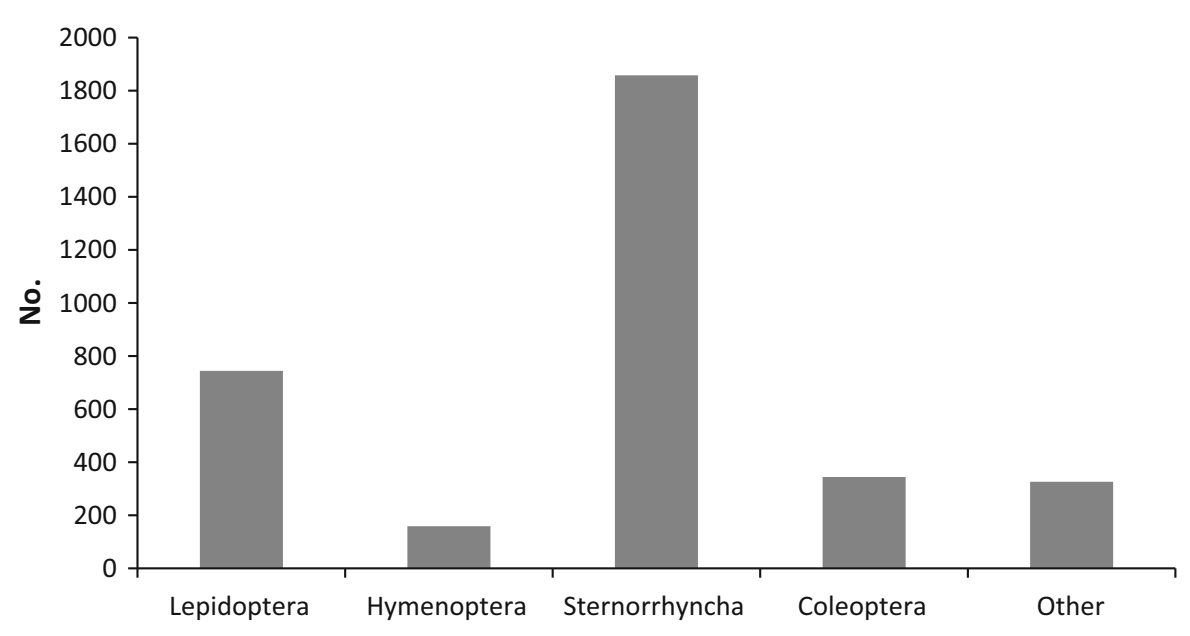

Fig. 5 Numbers of introductions of parasitoids and predators against different insect orders or sub-orders on woody plants

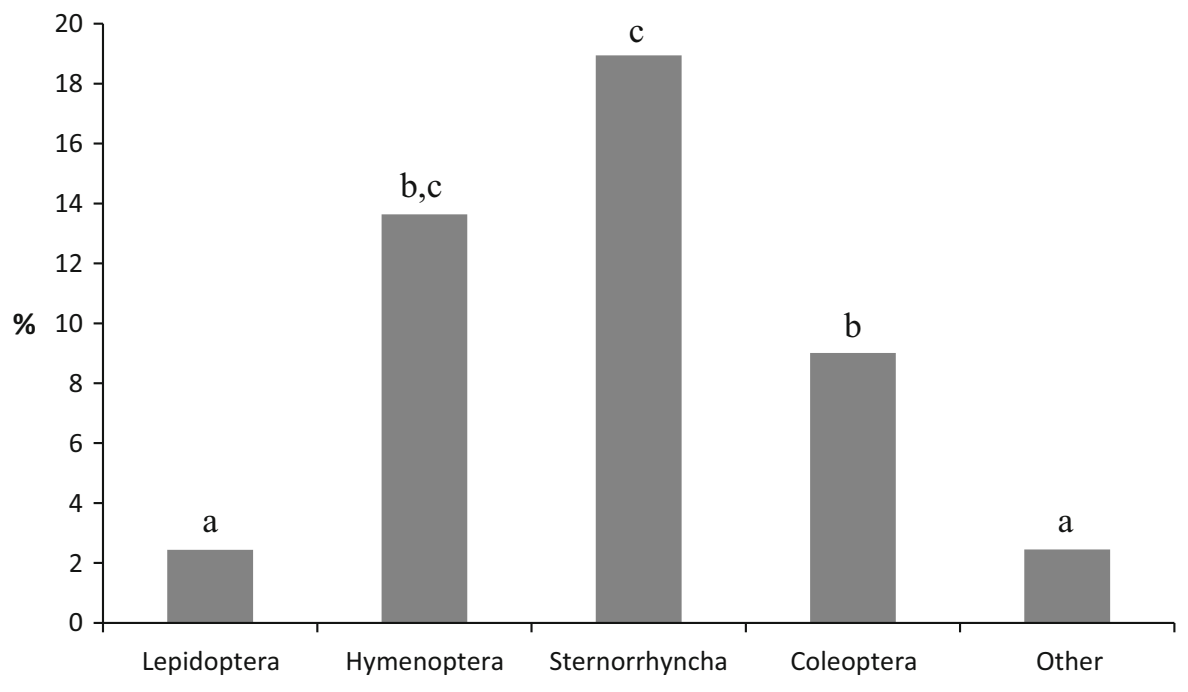

Fig. 6 Percentages of introductions of parasitoids and predators against different insect orders or sub-orders on woody plants, leading to $\mathrm{CBC}$ successes. Chi square tests, $5 \times 2$ table:

are very few cases of successful CBC programmes against bark beetles. An exception is the successful use of the specific predatory beetle $R$. grandis against the great spruce bark beetle in the Caucasus and Western Europe (Grégoire et al. 1992).

What are the risks of $\mathrm{CBC}$ and how can they be mitigated

Until the 1980s, CBC was considered and advertised as a very safe pest management activity. However,
$\mathrm{X}^{2}=173.3 ; d f=4 ; \mathrm{n}=3431 ; p<0.001$. Same letters above bars indicate homogenous groups at 0.05 level in $2 \times 2$ Chi square tests

following Howarth $(1983,1991)$, concerns began to emerge regarding the environmental safety of exotic biological control agents. Since then debates on nontarget effects, especially on native biodiversity have continued unabated. This debate, its consequences for $\mathrm{CBC}$ of insect pests, and efforts to mitigate the risks, have been very recently reviewed by Hajek et al. (2016b) and Van Driesche and Hoddle (2017) and, thus, the topic will not be re-discussed here at length. The main risk posed by the introduction of an exotic parasitoid, predator or entomopathogen is the potential 
direct effects on non-target organisms, i.e. by killing native hosts or prey, subsequently affecting populations and communities. Examples of direct effects on non-target host populations by exotic parasitoids are listed in Hajek et al. (2016b) and Van Driesche and Hoddle (2017), one of the most famous being the tachinid parasitoid $C$. concinnata, introduced to control the gypsy moth and presently suspected as causing the decline of native moths in North America (Elkinton and Boettner 2012). Non-target effects can also occur through intra-guild competition with, or predation on, closely-related species, for example, the invasive coccinellids Harmonia axyridis and Coccinella septempunctata and their effects on native coccinellids (Evans 2004; Roy et al. 2016). Introduced natural enemies can also hybridize with native, closely-related species or sub-species. For example, the torymid parasitoid Torymus sinensis, introduced in Japan against the chestnut gall wasp (Dryocosmus kuriphilus) is suspected to have caused the decline of the native Torymus beneficus by hybridization (Yara et al. 2007), although the mechanism of decline was more likely due to competition for hosts (Van Driesche and Hoddle 2017). Regardless, close examination of the literature has shown that relatively few introductions to date have directly impacted specific non-target species at the population level. However, other, indirect effects on native species and ecosystems are possible but more theoretical (Hajek et al. 2016b). In the last 20 years, biological control scientists and regulators have responded through the development of international guidelines, national regulations and scientific methods for risk assessment procedures. A particular emphasis is now placed on host specificity assessments to avoid the introduction of generalist natural enemies. Also, the costs and benefits associated with biological control are now better taken into account in the decision processes.

Has CBC declined since the rise of concerns for environmental impacts?

Figures 7 and 8 indeed show a decline in the numbers of introductions and the numbers of targeted pest species in the last decades, for pests of both woody and herbaceous plants. This decline of introduction events started before the expression of concerns for non-target effects in the 1990s, probably because of the growth of pesticide use after the Second World War. However, the decline continued and even increased in the 1990s despite increasing concerns for the harmful effects of pesticides on human health and the environment, suggesting that criticisms towards $\mathrm{CBC}$ may have had an effect on the amount of introductions. It is not possible to draw conclusions from the decline observed since 2000 because of delays in evaluating and reporting $\mathrm{CBC}$ activities, considering that the literature coverage of BIOCAT2010 ends in 2010.

\section{Has CBC declined more in forestry compared to agriculture?}

Considering the supposedly lower importance of forestry and ornamental pests for human livelihood compared to agricultural pests and, consequently, the higher potential benefits of $\mathrm{CBC}$ in the agricultural sector, we could expect that the increasing concern for non-target effects would affect more CBC programmes against forestry and ornamental pests than agricultural pests. In fact, as shown in Fig. 9, it seems that, in the last decades, CBC declined much more in the agricultural sector (both for pests of herbaceous plants and orchards/plantations) than in the forestry and ornamental sectors. Since the 1980s, the number of projects against pests of woody and herbaceous crop plants dropped dramatically whereas those targeting pests of forestry and ornamental plants remained remarkably stable, possibly because there are fewer alternative management methods in forest and urban environments than in agricultural systems.

Does CBC against exotic tree pests still have a future and what will be the biggest constraints to its wider application?

Globally, insect invasions have increased dramatically in the last two decades because of the rapid escalation of international trade (Roques et al. 2016; Seebens et al. 2017). In parallel, the use of insecticides is increasingly banned or severely restricted in forests and urban ecosystems. In many cases, the introduction of exotic natural enemies represents the only sustainable management solution, in particular when the pest occurs over wide areas and in protected ecosystems (Van Driesche et al. 2010). This situation is potentially very favourable for CBC worldwide. However, there are several constraints that hamper the wider application of CBC. 
Fig. 7 Numbers of introductions of parasitoids and predators in $\mathrm{CBC}$ programmes against introduced pests of woody and herbaceous plants, presented per decade until 2010

Fig. 8 Numbers of plant pests of woody and herbaceous plants targeted in CBC programmes, presented per decade until 2010

Fig. 9 Numbers of plant pests of woody and herbaceous plants targeted in CBC programmes, presented per crop system and per decade until 2010
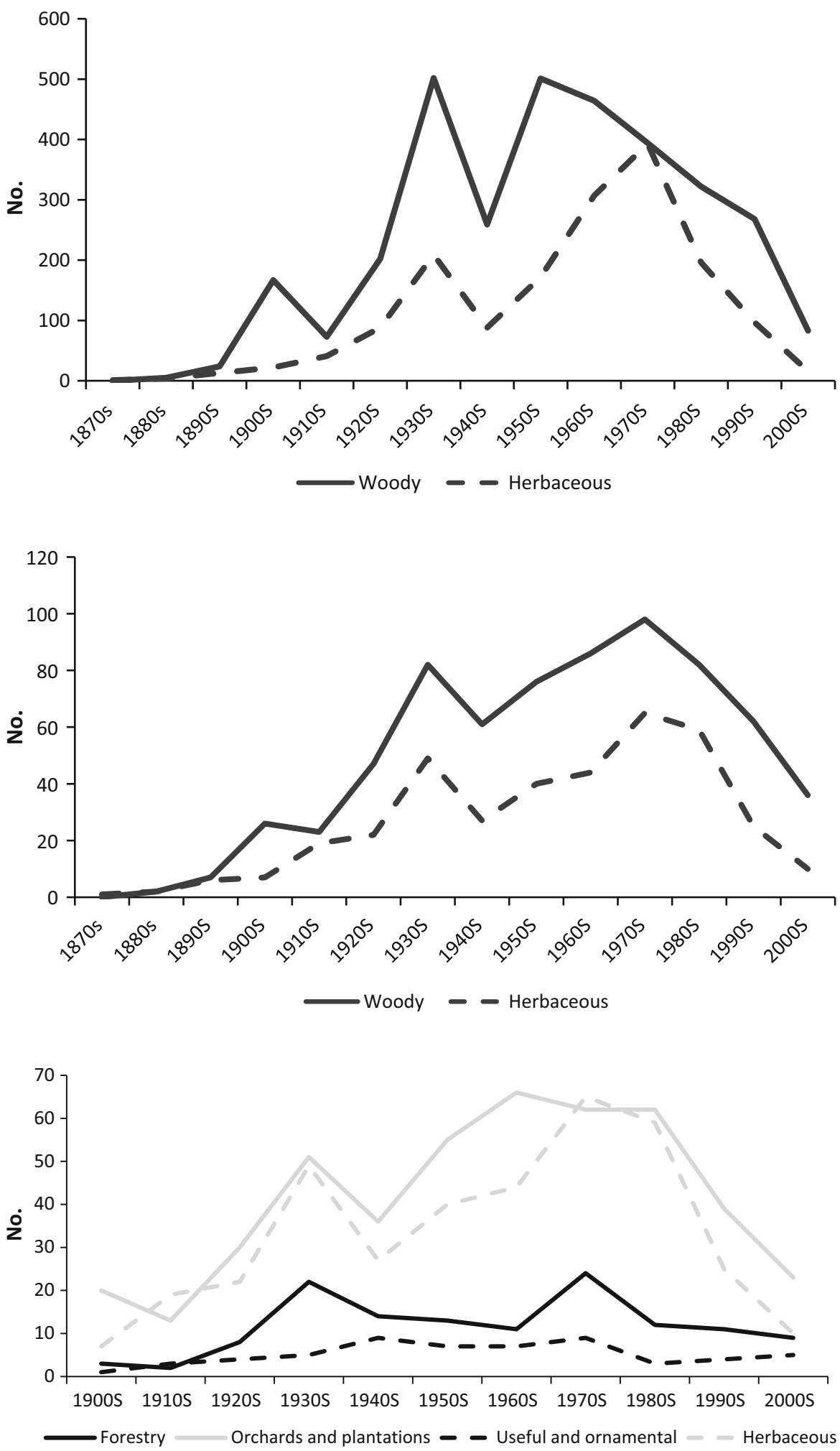
One of the main constraints to the use of $\mathrm{CBC}$ is due to the changes in legislation. Because of concerns about negative environmental impacts, many countries have now developed legislation aimed to limit the risk of non-target effects of CBC agents. Such legislation is important to ensure the responsible use of CBC. However, unfortunately in some cases it is so strict that it blocks all possibilities for importation of natural enemies, or at least discourages pest management practitioners to consider CBC as an option. This is an unfortunate outcome of such legislation, given that the alternative pest management strategies generally pose much higher environmental risks.

Another legislative constraint on the use of CBC has been the ratification of the Nagoya Protocol on Access and Benefit Sharing based on the Convention on Biological Diversity. This requires countries to legislate for access to their genetic resources, which includes potential biological control agents. Although well intended, implementation of this legislation has caused confusion and lack of certainty regarding procedures in many countries, making it difficult to import $\mathrm{CBC}$ agents from these countries. Some countries have been reported to inadvertently or deliberately establish barriers to the export and use of CBC agents (Cock et al. 2010). However, hopefully, in the coming years, procedures based on new legislation will be optimised and clarified to allow access and use of CBC agents.

Apart from legislation, poor perception of CBC by the public and even other scientists, such as ecologists, poses a major challenge to the future use of CBC (Van Driesche et al. 2016). Although this negative perception is largely unwarranted, given the very low percentage of non-target impacts (Hajek et al. 2016b; Van Driesche and Hoddle 2017), in some cases, biological control practitioners are themselves responsible for the negative image of $\mathrm{CBC}$ in the public and the scientific community. For example, the generalist harlequin ladybird $(H$. axyridis) was released in Europe in the 1990s and early 2000s, although reports of non-target effects were already available from North America; these releases have caused tremendous damage to the image of biological control in Europe (Roy et al. 2016). Thus, it is also the role of the biological control community, by following good practices, to ensure that CBC and other biological control practices are widely accepted and considered as a valuable and safe tool to control exotic pests.
Acknowledgements We thank Sandy Liebhold for the invitation to participate in the IUFRO Task Force on Biological Invasions and to write this review.

Open Access This article is distributed under the terms of the Creative Commons Attribution 4.0 International License (http:// creativecommons.org/licenses/by/4.0/), which permits unrestricted use, distribution, and reproduction in any medium, provided you give appropriate credit to the original author(s) and the source, provide a link to the Creative Commons license, and indicate if changes were made.

\section{References}

Boavida C, Garcia A, Branco M (2016) How effective is Psyllaephagus bliteus (Hymenoptera: Encyrtidae) in controlling Glycaspis brimblecombei (Hemiptera: Psylloidea)? Biol Control 99:1-7

Bush SJ, Slippers B, Neser S, Harney M, Dittrich-Schröder G, Hurley BP (2016) Six recently recorded Australian insects associated with Eucalyptus in South Africa. Afr Entomol 24:539-544

Carl KP (1982) Biological control of native pests by introduced natural enemies. Biocontrol News Info 3:191-200

Charles JG (1998) The settlement of fruit crop arthropod pests and their natural enemies in New Zealand: an historical guide to the future. Biocontrol News Inf 19:47N-58N

Cock MJW, van Lenteren JD, Brodeur J, Barratt BIP, Bigler F, Bolckmans K, Cônsoli FL, Haas F, Mason PG, Parra JRP (2010) Do new Access and Benefit Sharing procedures under the Convention on Biological Diversity threaten the future of biological control? Biocontrol 55:199-218

Cock MJW, Day RK, Hinz HL, Pollard KM, Thomas SE, Williams FE, Witt ABR, Shaw RH (2015) The impacts of some classical biological control successes. CAB Rev 10:042

Cock MJW, Murphy ST, Kairo MTK, Thompson E, Murphy RJ, Francis AW (2016) Trends in the classical biological control of insect pests by insects: an update of the BIOCAT database. Biocontrol 61:349-363

Colautti RI, Ricciardi A, Grigorovich IA, Hj MacIsaac (2004) Is invasion success explained by the enemy release hypothesis? Ecol Lett 7:721-733

Cornell HV, Hawkins BA (1993) Accumulation of native parasitoid species on introduced herbivores: a comparison of hosts as natives and hosts as invaders. Am Nat 141:847-865

Dahlsten DL, Mills NJ (1999) Biological control of forest insects. In: Bellows TS, Fisher TW, Caltagirone LE, Dahlsten DL, Gordh G, Huffaker CB (eds) Handbook of biological control. Academic Press, San Diego, pp 761-788

Dahlsten DL, Hansen EP, Zuparko RL, Norgaard RB (1998) Biological control of the blue gum psyllid proves economically beneficial. Calif Agric 52:35-40

Desurmont GA, Donoghue MJ, Clement WL, Agrawal AA (2011) Evolutionary history predicts plant defense against an invasive pest. Proc Natl Acad Sci USA 108:7070-7074 
Elkinton JS, Boettner GH (2012) Benefits and harm caused by the introduced generalist tachinid, Compsilura concinnata, in North America. Biocontrol 57:277-288

Evans EW (2004) Habitat displacement of North American ladybirds by an introduced species. Ecology 85:637-647

Fowler SV (2004) Biological control of an exotic scale, Orthezia insignis Browne (Homoptera: Ortheziidae), saves the endemic gumwood tree, Commidendrum robustum (Roxb.) DC. (Asteraceae) on the island of St. Helena. Biol Control 29:367-374

Garnas JR, Hurley BP, Slippers B, Wingfield MJ (2012) Biological control of forest plantation pests in an interconnected world requires greater international focus. Int J Pest Manag 58:211-223

Georgiev G, Mirchev P, Georgieva M, Matova M (2014) New localities of Entomophaga maimaiga and suppressing of Lymantria dispar calamity in northwest Bulgaria. Nauka za Gorata 50:75-85

Godfray HCJ, Agassiz DLJ, Nash DR, Lawton JH (1995) The recruitment of parasitoid species to two invading herbivores. J Anim Ecol 64:393-402

Grabenweger G, Kehrli P, Zweimueller I, Augustin S, Avtzis N, Bacher S, Freise J, Girardoz S, Guichard S, Heitland W, Lethmayer C, Stolz M, Tomov R, Volter L, Kenis M (2010) Temporal and spatial variations in the parasitoid complex of the horse chestnut leafminer during its invasion of Europe. Biol Invasions 12:2797-2813

Greathead DJ, Greathead AH (1992) Biological control of insect pests by insect parasitoids and predators: the BIOCAT database. Biocontrol News Inf 13:61N-68N

Grégoire JC, Couillien D, Drumont A, Meyer H, Francke W (1992) Semiochemicals and the management of Rhizophagus grandis Gyll. (Col., Rhizophagidae) for the biocontrol of Dendroctonus micans Kug. (Col., Scolytidae). J Appl Entomol 114:110-112

Gutierrez AP, Caltagirone LE, Meikle W (1999) Evaluation of results: economics of biological control. In: Bellows TS, Fisher TW (eds) Handbook of biological control. Academic Press, San Diego, pp 243-252

Hajek AE (2004) Natural enemies: an introduction to biological control. Cambridge University Press, Cambridge

Hajek AE, van Frankenhuyzen K (2016) Microbial control of forest insects. In: Lacey L (ed) Microbial agents for control of insect pests: from theory to practice. Academic Press, Cambridge

Hajek AE, McManus ML, Delalibera Junior I (2007) A review of introductions of pathogens and nematodes for classical biological control of insects and mites. Biol Control 41:1-13

Hajek AE, Tobin PC, Haynes KJ (2015) Replacement of a dominant viral pathogen by a fungal pathogen does not alter the synchronous collapse of a forest insect outbreak. Oecologia 177:785-797

Hajek AE, Gardescu S, Delalibera Jr I (2016a) Classical biological control of insects and mites: a worldwide catalogue of pathogen and nematode introductions. USDA Forest Service. FHTET-2016-06

Hajek AE, Hurley BP, Kenis M, Garnas JR, Bush SJ, Wingfield MJ, van Lenteren JC, Cock MJ (2016b) Exotic biological control agents: a solution or contribution to arthropod invasions? Biol Invasions 18:953-969
Henery ML (2011) The constraints of selecting for insect resistance in plantation trees. Agric For Entomol 13:111-120

Hill G, Greathead D (2000) Economic evaluation in classical biological control. In: Perrings $\mathrm{C}$, Williamson $\mathrm{MH}$, Dalmazzone $\mathrm{S}$ (eds) The economics of biological invasions. Edward Elgar, Cheltenham, pp 208-225

Hokkanen HMT, Pimentel D (1984) New approach for selecting biological control agents. Can Entomol 116:1109-1121

Hokkanen HMT, Pimentel D (1989) New associations in biological control: theory and practice. Can Entomol 121:829-840

Howarth FG (1983) Classical biocontrol: panacea or Pandora's box. Proc Hawaii Entomol Soc 24:239-244

Howarth FG (1991) Environmental impacts of classical biological control. Annu Rev Entomol 36:485-509

Jeffries MJ, Lawton JH (1984) Enemy free space and the structure of ecological communities. Biol J Linn Soc 23:269-286

Keane RM, Crawley MJ (2002) Exotic plant invasions and the enemy release hypothesis. Trends Ecol Evol 17:164-170

Kenis M (2005) Insects-insecta. In: Wittenberg R (ed) An inventory of alien species and their threat to biodiversity and economy in Switzerland. CABI Bioscience Switzerland. Centre report to the Swiss Agency for Environment, Forests and Landscape, pp 131-212

Kenis M, Branco M (2010) Chapter 5: Impact of alien terrestrial arthropods in Europe. In: Roques A, Kenis M, Lees D, Lopez-Vaamonde C, Rabitsch W, Rasplus J-Y, Roy D (eds) Alien terrestrial arthropods of Europe. BioRisk 4:51-71

Kenis M, Wermelinger B, Grégoire JC (2004) Research on parasitoids and predators of Scolytidae, a review. In: Lieutier F, Day KR, Battisti A, Grégoire J-C, Evans HF (eds) Bark and wood boring insects in living trees in Europe: a synthesis. Kluwer, Dordrecht, pp 237-290

Kuris AM (2003) Did biological control cause extinction of the coconut moth, Levuana iridescens, in Fiji? Biol Invasions $5: 133-141$

Lockwood JA (1993) Environmental issues involved in biological control of rangeland grasshoppers (Orthoptera: Acrididae) with exotic agents. Environ Entomol 22:503-518

Lovett GM, Weiss M, Liebhold AM, Holmes TP, Leung B, Lambert KF, Orwig DA, Campbell FT, Rosenthal J, McCullough DG, Wildova R, Ayres MP, Canham CD, Foster DR, LaDeau SL, Weldy T (2016) Nonnative forest insects and pathogens in the United States: impacts and policy options. Ecol Appl 26:1437-1455

MacQuarrie CJK (2008) Invasion history, population dynamics and biological control of Profenusa thomsoni (Konow) in Alaska. University of Alberta, Edmonton

Mason P, Huber J (eds) (2002) Biological control programmes against insects and mites, weeds, and pathogens in Canada 1981-2000. CABI, Wallingford

Montgomery ME, Havill NP (2014) Balsam woolly adelgid, chapter II. In: Van Driesche RG, Reardon R (eds) The use of classical biological control to preserve forests in North America. United States Department of Agriculture, Forest Service, Morgantown, WV, FHTET-2013-2

Nealis VG, Carter N, Kenis M, Quednau FW, van Frankenhuyzen K (2002) Lymantria dispar (L.), Gypsy Moth 
(Lepidoptera: Lymantriidae). In: Mason P, Huber J (eds) Biological control programmes against insects and mites, weeds, and pathogens in Canada 1981-2000. CABI, Wallingford, pp 159-168

Neuenschwander P (2001) Biological control of the cassava mealybug in Africa: a review. Biol Control 21:214-229

Nielsen C, Milgroom MG, Hajek AE (2005) Genetic diversity in the gypsy moth fungal pathogen Entomophaga maimaiga from founder populations in North America and source populations in Asia. Mycol Res 109:941-950

Pautasso M, Aas G, Queloz V, Holdenrieder O (2013) European ash (Fraxinus excelsior) dieback-a conservation biology challenge. Biol Conserv 158:37-49

Pimentel D (1963) Introducing parasites and predators to control native pests. Can Entomol 95:785-792

Pschorn-Walcher H (1977) Biological control of forest insects. Ann Rev Entomol 22:1-22

Rebek EJ, Herms DA, Smitley DR (2008) Interspecific variation in resistance to emerald ash borer (Coleoptera: Buprestidae) among North American and Asian ash (Fraxinus spp.). Environ Entomol 37:242-246

Roques A, Auger-Rozenberg MA, Blackburn TM, Garnas J, Pyšek P, Rabitsch W, Richardson DM, Wingfield MJ, Liebhold AM, Duncan RP (2016) Temporal and interspecific variation in rates of spread for insect species invading Europe during the last 200 years. Biol Invasions 18:907-920

Roy HE, Brown PMJ, Adriaens T, Berkvens N, Borges I, Clusella-Trullas S, De Clercq P, Comont RF, Eschen R, Estoup A, Evans EW, Facon B, Gardiner MM, Gil A, Grez AA, Guillemaud T, Haelewaters D, Herz A, Honek A, Howe AG, Hui C, Hutchison WD, Kenis M, Koch RL, Kulfan J, Lawson Handley L, Lombaert E, Loomans A, Losey J, Lukashuk AO, Maes D, Magro A, Murray KM, San Martin G, Martinkova Z, Minnaar IA, Nedved O, Orlova-Bienkowskaja MJ, Rabitsch W, Ravn HP, Rondoni G, Rorke SL, Ryndevich SK, Saethre M-G, Sloggett JJ, Soares AO, Stals R, Tinsley MC, Vandereycken A, van Wielink P, Viglášová S, Zach P, Zakharov IA, Zaviezo T, Zhao Z (2016) The harlequin ladybird, Harmonia axyridis: global perspectives on invasion history and ecology. Biol Invasions 18:997-1044

Safranyik L, Shore TL, Moeck HA, Whitney HS (2002) Dendroctonus ponderosae Hopkins, mountain pine beetle (Coleoptera: Scolytidae). In: Mason P, Huber J (eds) Biological control programmes against insects and mites, weeds, and pathogens in Canada 1981-2000. CABI, Wallingford, pp 104-109

Seebens H, Blackburn T, Dyer EE, Genovesi P, Hulme PE, Jeschke JM, Pagad S, Pyšek P, Winter M, Arianoutsou M, Bacher S, Blasius B, Brundu G, Capinha C, Celesti-Grapow L, Dawson W, Dullinger S, Fuentes N, Jäger H, Kartesz J, Kenis M, Kreft H, Kühn I, Lenzner B, Liebhold A, Mosena A, Moser D, Nishino M, Pearman D, Pergl J, Rabitsch W, Rojas-Sandoval J, Roques A, Rorke S, Rossinelli S, Roy HE, Scalera R, Schindler S, Štajerová K, Tokarska-Guzik B, van Kleunen M, Walker K, Weigelt P, Yamanaka T, Essl F (2017) No saturation in the accumulation of alien species worldwide. Nat Commun 8:14435

Soper AL, MacQuarrie CJ, Van Driesche R (2015) Introduction, establishment, and impact of Lathrolestes thomsoni
(Hymenoptera: Ichneumonidae) for biological control of the ambermarked birch leafminer, Profenusa thomsoni (Hymenoptera: Tenthredinidae), in Alaska. Biol Control 83:13-19

Sweeney J, Brockerhoff E, Kenis M, Turgeon JJ (2002) Strobilomyia neanthracina and S. appalachensis, Spruce Cone Maggots (Diptera: Anthomyiidae). In: Mason P, Huber J (eds) Biological control programmes against insects and mites, weeds, and pathogens in Canada 1981-2000. CABI, Wallingford, pp 253-258

Tisdell CA (1990) Economic impact of biological control of weeds and insects. Critical issues in biological control. In: Mackauer M, Ehler J, Roland J (eds) critical issues in biological control. Intercept Ltd, Auckland, pp 301-316

Van Driesche RG, Bellows TS Jr (1996) Biological Control. Chapman and Hall, New York

Van Driesche RG, Hoddle MS (2017) Non-target effects of insect biocontrol agents and trends in host specificity since 1985. CABI Rev (in press)

Van Driesche RG, Reardon R (eds) (2014) The use of classical biological control to preserve forests in North America. United States Department of Agriculture, Forest Service, Morgantown, WV, FHTET-2013-2

Van Driesche R, Hoddle M, Center T (2008) Control of pests and weeds by natural enemies. Blackwell Publishing Limited, Malden

Van Driesche RG, Carruthers RI, Center T, Hoddle MS, HoughGoldstein J, Morin L, Smith L, Wagner DL, Blossey B, Brancatini V, Casagrande R, Causton CE, Coetzee JA, Cuda J, Ding J, Fowler SV, Frank JH, Fuester R, Goolsby J, Grodowitz M, Heard TA, Hill MP, Hoffmann JH, Huber J, Julien M, Kairo MTK, Kenis M, Mason P, Medal J, Messing R, Miller R, Moore A, Neuenschwander P, Newman R, Norambuena H, Palmer WA, Pemberton R, Perez Panduro A, Pratt PD, Rayamajhi M, Salom S, Sands D, Schooler S, Schwarzländer M, Sheppard A, Shaw R, Tipping PW, van Klinken RD (2010) Classical biological control for the protection of natural ecosystems. Biol Control 54(Suppl1):S2-S33

Van Driesche RG, Simberloff D, Blossey B, Causton C, Hoddle M, Marks CO, Heinz KM, Wagner DL, Warner KD (2016) Integrating biological control into conservation practice. Wiley, New York

Weseloh RM (1998) Possibility for recent origin of the gypsy moth (Lepidoptera: Lymantriidae) fungal pathogen Entomophaga maimaiga (Zygomycetes: Entomophthorales) in North America. Environ Entomol 27:171-177

West RJ, Kenis M (1997) Screening four exotic parasitoids as potential controls for the eastern hemlock looper, Lambdina fiscellaria fiscellaria (Guenée) (Lepidoptera: Geometridae). Can Entomol 129:831-841

West RJ, Kenis M, Bourchier R, Smith S, Butt G (2002) Zeiraphera canadensis Mutuura and Freeman, Spruce Bud Moth (Lepidoptera: Tortricidae). In: Mason P, Huber J (eds) Biological control programmes against insects and mites, weeds, and pathogens in Canada 1981-2000. CABI, Wallingford, pp 279-283

Winston RL, Schwarzländer M, Hinz HL, Day MD, Cock MJW, Julien MH (eds) (2014) Biological control of weeds: a world catalogue of agents and their target weeds, 5th edn. 
United States Department of Agriculture, Forest Service, Morgantown, WV, FHTET-2014-04

Yara K, Sasawaki T, Kunimi Y (2007) Displacement of Torymus beneficus (Hymenoptera: Torymidae) by T. sinensis, an indigenous and introduced parasitoid of the chestnut gall wasp, Dryocosmus kuriphilus (Hymenoptera: Cynipidae), in Japanese chestnut fields: possible involvement in hybridization. Biol Control 42:148-154 